\title{
Frida Kahlo and her doctors
}

\section{John Launer}

The two great Mexican painters, Frida Kahlo and her husband Diego Rivera, were among the earliest media celebrities. They were so widely known in the 1930's and $40 \mathrm{~s}$ that people across America and in Europe often referred to them just by their first names, and would have instantly recognised any image of them. Visually, they were a spectacular couple. Frida was small, delicate, androgynous and arrestingly beautiful. Diego was twenty years older, three times her weight, bulbouseyed and impressively ugly. While pursuing their respective careers as the greatest self-portraitist and muralist of their age, they each led luridly promiscuous love lives. They set the trend for future celebrities by divorcing and then remarrying. They both confabulated outrageously, telling melodramatic and contradictory versions of their own or each others' stories. Among their acquaintance they included Pablo Picasso, the billionaire John D Rockefeller, and the Russian revolutionary Leon Trotsky, with whom Frida had an affair while he was their house guest.

Frida's medical history was notoriously tragic. She was born in 1907 with an undiagnosed scoliosis. At the age of six, she contracted polio (or a polio-like illness) that affected the muscles of her right leg. ${ }^{1}$ With characteristic will-power, she recovered well enough to run and dance, but at 18 she was a passenger in a catastrophic collision, when a bus she was travelling on was sliced in two by a tram. Frida was impaled by a severed handrail that pierced the left side of her abdomen and emerged through her pelvic outlet. She sustained multiple fractures including eleven in her weak right leg, dislocation and crush fractures of her right foot, as well as fractures of her lumbar spine that were only discovered some months later. The accident determined the rest of her life. She gave up an ambition to study medicine, and taught herself painting instead. In the course of her life she underwent at least thirty orthopaedic and other operations, although many appear to have been unnecessary or unsuccessful. For intermittent periods she was encased in plaster or

Associate Editor, Postgraduate Medical Journal, London, UK

Correspondence to Dr John Launer; johnlauner@aol.com in metal corsets, or kept in traction. She had several abortions and at least one devastating miscarriage.

As well as relieving her pain and despair with alcohol, Frida eventually became addicted to morphine. She smoked constantly. She contracted probable syphilis. In her forties she developed gangrene, for which she needed amputation of her right foot and then the leg. In spite of all this horrendous adversity, she carried on almost to the end of her life with a youthfulness, grace and energy that would be literally unbelievable if these had not been recorded on film and photographs. ${ }^{2} 3$

\section{LEO ELOESSER 'MY BEST FRIEND'}

Frida's experience of illness, injury, pain and suffering were often at the centre of her work. Her paintings offer a visual chronicle of this, as well as encompassing her family, marriage, relationships, dedication to communism and love for Mexican scenery, culture and costume. She saw scores of doctors over the years, but two of these had a significant presence in her paintings, as they did in her treatment. Her relationship with these men was of a piece with everything else she did, bringing together expertise with

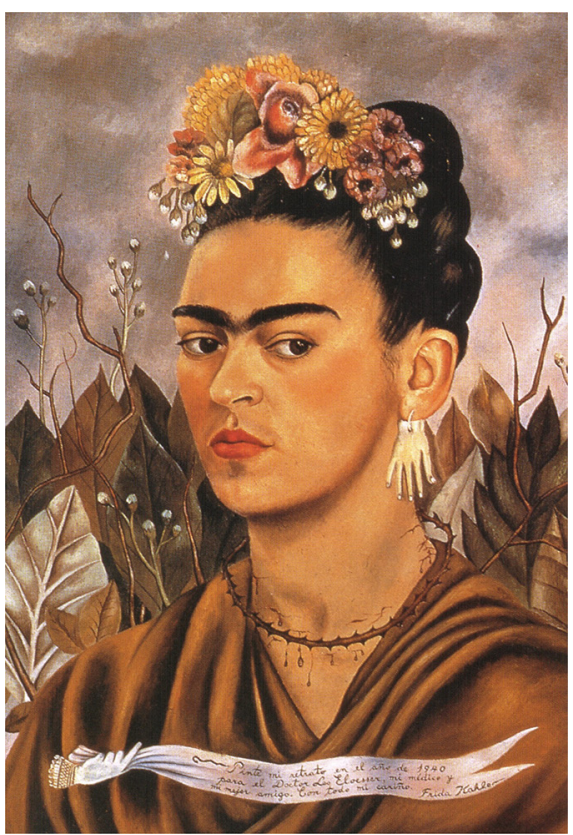

Figure 1 Self-portrait dedicated to $\operatorname{Dr}$ Leo Eloesser, 1940. @ Banco de México Diego Rivera Frida Kahlo Museums Trust, Mexico, D.F. I DACS 2018. intimacy, and transcending the separation of art and life.

The most important of her medical attendants was Leo Eloesser. He was an renowned thoracic surgeon whom she first consulted in San Francisco in 1930. She came to trust his judgement so completely that she confided in him for the rest of her life, writing him long, affectionate letters asking for medical guidance and advice about her personal life. ${ }^{4}$ She addressed him as 'Dearest Doctorcito' and held back little or nothing from him. During her period of divorce he wrote to her about Diego: 'He has never been, nor ever will be, monogamous, something that is imbecilic and anti-biological.' Eloesser's life was as unconventional as his advice. He owned a sloop called 'The Flirt', which he would take out sailing all night in the Pacific between shifts at the hospital, and in which he often took out women friends. He was an accomplished musician, and spoke at least twelve languages, including Chinese and Japanese. During the Spanish civil war, he volunteered with the loyalists against General Franco and set up a military hospital. After retirement in 1945 he worked for the United Nations Relief Organisation in China, but quietly went over to the communists, living like a peasant and teaching 'barefoot doctors' for 4 years before returning to America. ${ }^{5}$

Frida once painted his portrait, showing him alongside a model of his sloop. ${ }^{6} \mathrm{~A}$ far more impressive work, however, is the self-portrait she dedicated to him during the year of her divorce - one of the most striking she ever did in her career (see figure 1). Frida's portrayal of herself in the painting is typical, with her eyebrows meeting in the middle, a faint moustache and full lips, and characteristic olive complexion. (She was Spanish Aztec on her mother's side, and Hungarian Jewish on her father's). She presents herself as a martyr, wearing Christ's crown of thorns as a necklace that pierces her skin and draws blood. The extravagant bouquet in her hair and lush foliage in the background are offset by long, dry, brown twigs on either side of her. A hand-shaped earring suggests emotional and physical amputation. A hand-shaped brooch matches it, holding a ribbon on which she has written "I painted my portrait in the year 1940 for Dr. Eloesser, my doctor and my best friend. With all love, Frida Kahlo.' Her expression is sad, haughty and vulnerable. It depicts both her suffering and her mastery of it. The portrait was a expression of how she saw herself and wished her American doctor to see her. In the words of her biographer Hayden Herrera, 'she turns herself into an icon that she - and 


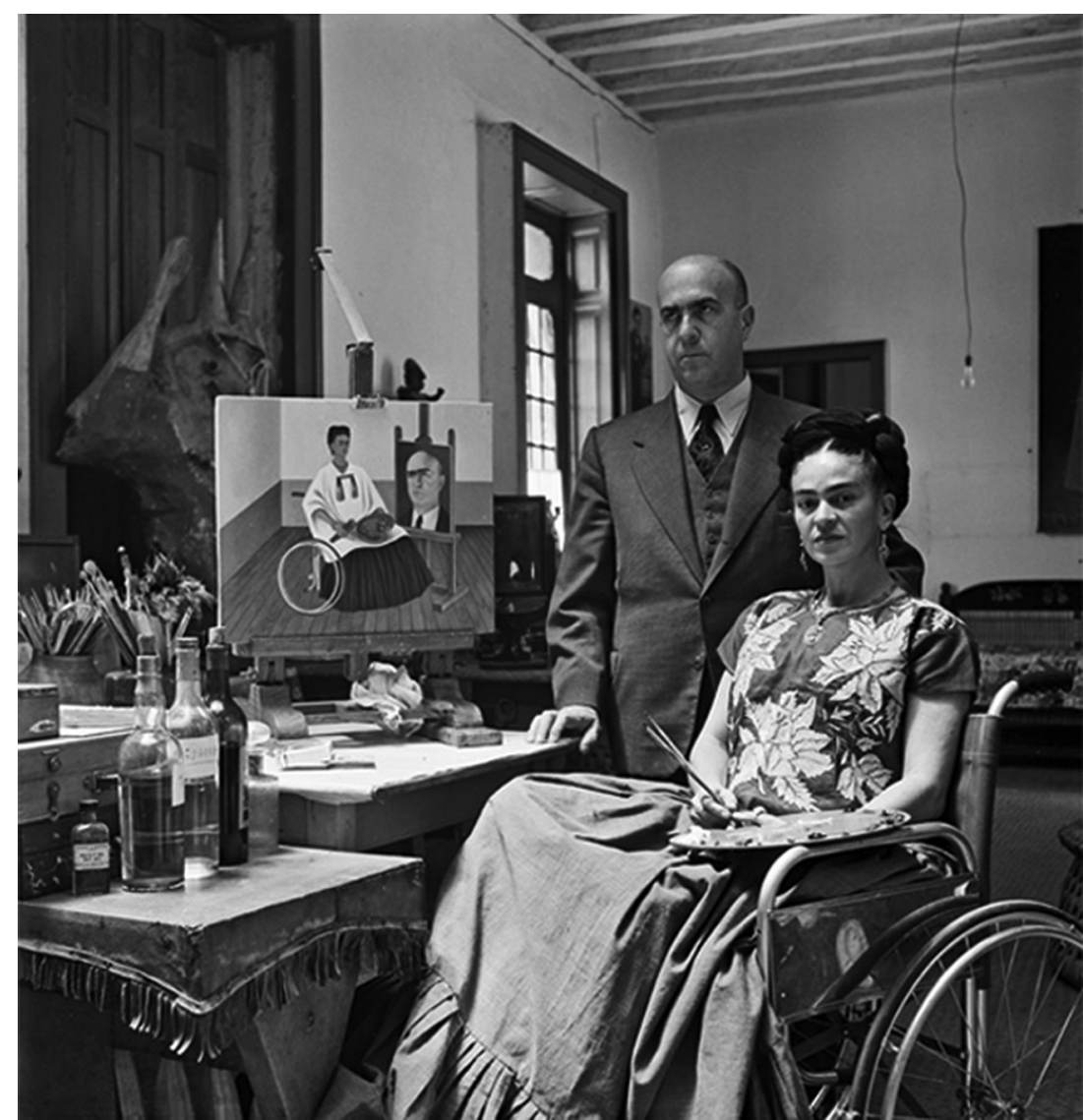

Figure 2 Frida Kahlo in her studio with Dr Juan Farill, photographed by Gisèle Freund, 1951. (c) Banco de México Diego Rivera Frida Kahlo Museums Trust, Mexico, D.F. / DACS 2018.

others - can worship, thus transcending pain.'

\section{JUAN FARILL 'THE MOST SERIOUS' DOCTOR}

At the time she did the portrait, Frida had also begun to consult with an orthopaedic surgeon in Mexico City called Juan Farill. He was himself a painter and, like Eloesser, became her close friend. He carried out her last seven operations, including removal of a spinal plate and insertion of a bone graft from her pelvis. Later, he was also to take charge of her amputations. She wrote to Dr Eloesser to say that she trusted Farill because he seemed the 'most serious' of the five local doctors she had recently seen. He certainly looks serious in a remarkable photo that he and Frida posed for in her studio with her in a wheelchair and him standing protectively behind her (see figure 2). On an easel in the background there is a votive self-portrait she completed in thanks for recovering from her bone graft. It shows her sitting in front of a further easel displaying a painting of Farill. ${ }^{7}$ Each of the three nested images are rich in meaning. Farill gazes into the of her identity. ical and psychological disintegration. had developed bronchopneumonia and possibly suffered a pulmonary embolus. She may also have taken an intentional or accidental overdose of morphine. Leo Eloesser had moved to Mexico by this time, setting up a clinic to treat the disadvantaged, and donating his fees to charity. Dr Juan Farill pioneered contrast myelography for disc lesions, and arteriography for bone tumours, as well as the skeletal traction Frida had used. He went on to publish a total of 87 scientific and popular works. As well as being one of the most exceptional cultural figures of the twentieth century, Frida Kahlo had chosen as her chief doctors, as confidants and companions, and as subjects for her own portraits, two quite extraordinary men.

Competing interests None declared

Patient consent Not required.

Provenance and peer review Commissioned; internally peer reviewed.

(c) Article author(s) (or their employer(s) unless otherwise stated in the text of the article) 2018. All rights reserved. No commercial use is permitted unless otherwise expressly granted.

\section{Deck for updates}

To cite Launer J. Postgrad Med J 2018;94:369-370.

Received 5 March 2018

Accepted 5 March 2018

Postgrad Med J 2018;94:369-370.

doi:10.1136/postgradmedj-2018-135705 contemplatively in the self-portrait, but with a little more sadness in real life, and possibly defiance. In the painted version of Farill, his eyebrows are joined together just like Frida's, as if he had absorbed part

The poses in the photo carefully mirror those in the self-portrait. However, in the photo Frida is holding her everyday artist's palette, while in the self-portrait it is painted over with a anatomical depiction of a heart. This looks as if it has been torn from her chest, and she seems to be offering it directly to Farill in the manner of an Aztec sacrifice to the gods. The brushes in her other hand are like arrows or scalpels and drip with blood. The floral blouse that Frieda is wearing for the photo contrasts with the austere white one with silk tassels that she wears in the portrait. It is hard to imagine that Frida herself did not take charge of the entire composition in order to convey, as she always did, a sense of profound artistic control over the threats she faced of phys-

Three years after the photo was taken, Frida died at the age of only 47 . She

\section{REFERENCES}

1 Herrera H. Frida: the biography of Frida Kahlo. New York: Harper and Row, 1983.

2 Open Culture. Watch moving short films of Frida Kahlo and Diego Rivera at the "Blue House". 2013 http://www.openculture.com/2013/01/emotionallymoving_short_film_of_frida_kahlo_and_diego_ rivera_at_the_blue_house.html (accessed 24 Feb 2018).

3 De Cortanze G, Audric L. Frida Kahlo: the Gisèle Freund photographs. New York: Abrams, 2015. http://www. missmoss.co.za/2015/03/31/frida-kahlo-the-giselefreund-photographs/ (accessed 24 Feb 2018).

4 Reef C. Leo and Frida: the doctor and the artist. Stanford Medicine 2013 http://sm.stanford.edu/archive/ stanmed/2013summer/article8.html (accessed 24 Feb 2018)

5 Blaidsdell W. Leo Eloesser: the remarkable story of a medical volunteer in Spain. The Volunteer $2016 \mathrm{http}: /$ www.albavolunteer.org/2016/12/leo-eloesser-theremarkable-story-of-a-medical-volunteer-in-spain/ (accessed 24 Feb 2018)

6 Frida Kahlo: Paintings, Biography, Quotes. Portrait of Dr Leo Eloesser, 1931 - by Frida Kahlo. https://www. fridakahlo.org/portrait-of-dr-leo-eloesser.jsp (accessed 24 Feb 2018).

7 Frida Kahlo: Paintings, Biography, Quotes. Self-portrait with the portrait of Doctor Farill, 1951 - by Frida Kahlo. https://www.fridakahlo.org/self-portraitwith-the-portrait-of-doctor-farill.jsp (accessed 24 Feb 2018) 